\title{
The Chairman's Annual Report for the Year 1970-1971
}

This year marks the end of the Fifth annual course of lectures and the 17th year of the activity of the Anglo-Byelorussian Society. Despite increasing financial commitments the year has been a success, and it is felt that we may look to the future with a considerable measure of confidence.

During the past year two new members have joined the Society, - $\mathrm{Mr}$ and Mrs Carpendale, who have for some years now been associated with Byelorussians at Pixton. This brings the existing number of members to thirty-two. In addition the Society has received several enquiries about conditions for membership, and there is a growing interest in the work of the Journal.

In the course of the past year a further number of the Journal of Byelorussian Studies was published (Vol. II No. 1 for the year 1969) and another number (Vol. II No. 2 for 1970) is expected to be distributed from the printers at the end of this month. The following number (Vol. II No. 3 for 1971) is also nearing completion, and the Editorial Committee plan to place it in the hands of the printers before the 1st of August. The Journal continues to arouse growing interest in academic circles both in Byelorussia and in the West. The circulation continues around the 500 mark, and this year income from sales of the Journal reached $£ 370.25$ as compared with $£ 231$ in 1969-1970, a notable improvement. Much of the credit for these results must go to Dr McMillin and the Editorial Committee, who have succeeded in bringing the Journal more or less up to date, and to Mr Michaluk for his efforts in publicising and distributing our publication. I should particularly like on this occasion to offer the Society's congratulations to Dr McMillin on receiving a well-earned Doctor's degree after submitting a remarkable thesis on the Byelorussian literary language in the 19th century. We are also pleased to welcome a growing number of new contributors to the Journal, both English and Byelorussian. These are very encouraging signs for the future.

The Society's Fifth annual lecture course was held once again at the Society of Antiquaries of London in Burlington House, Picadilly. Six lectures were read, of which two took place in the Lecture hall, three in the Council chamber and one in a lecture room of the Linneaian Society. Attendance varied between 38 and 20. The Council of the Society met on 10 December 1970 and 24 June 1971 to deal with the ordinary business of the Society and its activities. Most of our efforts have been directed towards seeking grants for our publications, and these are still continuing. It is thanks to a generous grant from the Byelorussian Charitable Trust that the Journal has increased 
in size, and we should like to record our deep appreciation of their assistance. Our thanks are also due on a similar count to our VicePresident, Bishop Cesłaŭ Sipovič.

At a reception held at the Byelorussian Club in Bradford in March 1971 , the Society was represented by the Hon. Secretary, who gave a brief address on the subject of Byelorussia. Two members of Parliament were present. On 15 May 1971 the Chairman of the Society attended the opening of the Francis Skaryna Byelorussian Library and Museum in Finchley, on which occasion he made a short speech on the intellectual and cultural achievements of the Byelorussian community in Great Britain.

In concluding this summary of the Society's activities in what has been an exceptionally busy year, I should like to thank all my colleagues on the Council and the Editorial Committee of the Journal for all their work, and the ordinary members of the Society for their constant and loyal support.

22 July 1971

AUBERON HERBERT

Chairman 